Article

\title{
Application of Bottom Ash as Filter Media for Construction Site Runoff Control
}

\author{
Ki Woong Bang ${ }^{1}$, Jin Chul Joo ${ }^{1, * \mathbb{C}}$, Jin Ho Kim ${ }^{1}{ }^{\mathbb{C}}$, Eunbi Kang ${ }^{1}$, Jongsoo Choi ${ }^{2}$, \\ Jung Min Lee ${ }^{2}$ and Yonghyok Kim ${ }^{3}$ D \\ 1 Dept. Civil and Environmental Engineering, Hanbat National Univ., Daejeon 34158, Korea; \\ bangkw@hanbat.ac.kr (K.W.B.); wlsgh113@nate.com (J.H.K.); eunbi@kwater.or.kr (E.K.) \\ 2 Land and Housing Institute, Dept. Intelligent City Water Resource Management, Daejeon 34047, Korea; \\ jongsoo@lh.or.kr (J.C.); andrew4502@lh.or.kr (J.M.L.) \\ 3 Resource Recycling Research Center, Korea South-East Power Co., Incheon 23120, Korea; yhkim@koenergy.kr \\ * Correspondence: jincjoo@hanbat.ac.kr; Tel.: +82-42-821-1264
}

Received: 28 February 2020; Accepted: 29 March 2020; Published: 1 April 2020

check for updates

\begin{abstract}
The potential application of bottom ash (BA) for construction site runoff control as an alternative filter media with high removal efficiency of total suspended solids (TSS) and longer operation period were evaluated. Both lab-scale single-layer and pilot-scale multi-layer filtration experiments were performed using BA filter media with different particle sizes and various volumetric flow rates. Due to the mesoporous, irregular, and spherical shape of gravel-size BA filter media used in this study, relatively low surface area, negligible pore volume, and greater pore size were observed. Both TSS removal efficiencies and clogging of BA filter media were a complex function of particle size of BA filter media and loading rate of TSS. Incoming TSS particles did not significantly penetrate beyond 46-cm BA filter media depth, accumulating on the upper layers and gradually forming a clogging layer to critical thickness, and finally the clogging filtration mechanism dominated the overall removal efficiency of TSS. Accumulation of TSS on BA filter media can be explained by the lumped sigmoidal empirical model, and an exponential decline in accumulation of TSS with depth results in minimal accumulation beneath the clogging layer. As practical implications, BA filter media depth of less than $46 \mathrm{~cm}$ is recommended with dual- or multi-media filters using mixtures of gravel-size BA and silt-size fine media, and a combination of detention basins can reduce frequent periodic de-clogging operation and management.
\end{abstract}

Keywords: bottom ash (BA); clogging; construction site runoff; filter media; filtration; total suspended solids (TSS)

\section{Introduction}

Construction activities (i.e., land grading, building, stockpiling, excavating, earth moving, etc.) expose loose sediment, which increases both sedimentation and erosion. During rainy weather, polluted stormwater runoff from construction activities flows to sewer systems and is discharged into local rivers and streams [1-3]. Beyond water quality concerns, polluted sediment and debris from construction activities cause local flood hazards by reducing the flow capacity of storm drains and sewer systems [1-3].

Due to the large amounts of land disturbed through construction activities, construction sites have been reported to be the largest contributors of sediment loading to surface waters [1-3]. During the construction, unimpeded large volumes of stormwater can reach receiving waters with various pollutants (i.e., solids, organic matter, nutrients, bacteria, oil and grease, and metals), and those pollutants can be acutely toxic to aquatic organisms and cause prolonged damage to the environment 
mainly resulting from sediment accumulation and habitat degradation [1-3]. Since sediment runoff rates from construction sites are typically 10 to 20 times greater than those of agricultural lands [3], and 1000 to 2000 times greater than those of forest lands [3], various stormwater best management practices (BMPs) (i.e., silt fencing, media filter, sedimentation ponds, and detention basins to treat surface runoff, and seeding and natural riparian wetlands to control soil erosion) have been developed and implemented to address sediment runoff in construction sites [1-3].

For stormwater BMPs, both hydraulic performances considering clogging risks and pollutant removal efficiency of filter media are key design parameters for stormwater filtration and infiltration systems utilizing various filter media (i.e., sand, soil, gravel, peat, or compost) with different surface area, depth, and profile [4-7]. Although filtration performance of various filter media is a complex function of the properties (i.e., arrangement, size distribution, surface area, and depth) of filter media [4-7] and the properties (i.e., particle size, distribution, and loading of sediment) of construction site runoff [5-8], the most widely used media is sand filters with high removal efficiency of particulates and with modest removal efficiency of bacteria and dissolved metals [7-10]. Since sand filters have greater adaptability by incorporating layers of other filter media to enhance pollutant removal efficiency, sand filters can be readily constructed either above or below ground as an end-of-pipe BMP or installed as basins or filter inlets [9-11].

Considering bottom ash (BA) particles generated by coal-fired power plants have angular shapes with porous textures and rough surfaces with particle sizes ranging from $0.075 \mathrm{~mm}$ to $40 \mathrm{~mm}$ [12] similar to both physical and surface properties of sand filter media, BA has the potential application for stormwater filtration and infiltration systems as an alternative filter media with high removal efficiency of total suspended solids (TSS) and longer operation period of filter system. In addition, a previous study indicated that no environmental impacts or ecological toxicity are expected [13] when BA has been used to treat surface runoff and to reduce soil erosion at construction sites. Since the Republic of Korea is expected to generate more than 14 million tons of coal combustion products in 2021 and the capacity of current disposal facilities is nearly saturated [14], the potential application of BA needs to be explored in order to increase the beneficial usage rate of BA as an alternative filter media to provide high TSS removal efficiency with both high filter loading capacities and late development of clogging for construction site runoff.

In this study, the potential application of BA for construction site runoff control as an alternative filter media with high removal efficiency of TSS and longer operation period was evaluated. Both lab-scale single-layer and pilot-scale multi-layer filtration experiments were performed using BA filter media with different particle sizes and various volumetric flow rates simulating surface runoff flowing over construction sites. The specific objectives of this study were to (1) investigate both physicochemical and leaching properties of BA, (2) evaluate the effects of particle size of BA and loading rate of TSS on the TSS removal efficiency, (3) estimate both premature and complete clogging in single-layer filtration experiments, (4) investigate removal efficiencies of TSS and turbidity in multi-layer filtration experiments, (5) estimate the filtered amounts of TSS with the various depths of BA filter media, (6) compare the removal efficiencies of TSS among various filter media, and finally (7) suggest the practical implications of BA for construction site runoff control as an alternative filter media.

\section{Materials and Methods}

\subsection{Bottom Ash Filter Media}

Bottom ash used in this study is generated, and pre-treated using integrated pre-treatment systems (i.e., cooling, separation of ferrous metal, crushing, and sieving) in local coal-fired power plants of Republic of Korea. In this study, since the fraction of BA particle size $(D)$ less than $3 \mathrm{~mm}$ contained most pollutants due to the high surface area [13], the fraction of BA particle size greater than $3 \mathrm{~mm}$ was selected, constituting greater than $50 \%$ of total BA generated. The selected BA was washed with deionized water, dried at room temperature, and additionally sieved to separate three groups for 
uniform gradations of 3-6 mm, 6-10 mm, and 10-20 mm. Particle size specification of BA with different sizes were summarized in Table 1, indicating that BA in three groups is classified as uniformly-graded and has relatively identical particles with $C_{u}$ value approximately equal to unity.

Both surface area and pore size distribution of BA were determined via a $\mathrm{N}_{2}$ adsorption analysis with a volumetric apparatus (TriStarTM II 3020, Micromeritics, GA, USA). The multi-point surface area was determined after low-temperature adsorption data were fitted by the Brunauer-Emmett-Teller (BET) method, and the total pore volume was determined. The surface topography was measured using a field emission scanning electron microscopy (SEM) (JEOL JSM-6300, JEOL USA Inc. Peabody, MA). The appropriate observation mode, accelerating voltage, probe current, and working distance were adjusted for best results, and three different magnifications (i.e., 500×, 3500×, and 7000×) of SEM images were obtained. In addition, energy-dispersive $X$-ray spectroscopy (EDS) was measured to analyze both elemental analysis or chemical characterization of BA.

Table 1. Particle size specification and physical properties of bottom ash used in this study.

\begin{tabular}{|c|c|c|c|c|c|c|c|c|}
\hline \multirow{2}{*}{$\begin{array}{l}\text { Range } \\
(\mathrm{mm})\end{array}$} & \multicolumn{3}{|c|}{ Diameter(mm) } & \multirow{2}{*}{$\begin{array}{c}\text { Coefficient of } \\
\text { Uniformity } C_{u}=\frac{D_{60}}{D_{10}}\end{array}$} & \multirow{2}{*}{$\begin{array}{l}\text { Coefficient of Curvature } \\
\qquad C_{c}=\frac{D_{30} 0^{2}}{D_{10} \cdot D_{60}}\end{array}$} & \multirow{2}{*}{$\begin{array}{l}\text { BET Surface } \\
\text { Area }\left(\mathrm{m}^{2} / \mathrm{g}\right)\end{array}$} & \multirow{2}{*}{$\begin{array}{l}\text { Pore Volume } \\
\quad\left(\mathrm{cm}^{3} / \mathrm{g}\right)\end{array}$} & \multirow{2}{*}{$\begin{array}{l}\text { Pore Size } \\
\quad(\mathrm{nm})\end{array}$} \\
\hline & $D_{10}$ & $D_{30}$ & $D_{60}$ & & & & & \\
\hline $3-6$ & 4.2 & 4.6 & 5.8 & 1.38 & 0.86 & 0.0393 & $5.4 \times 10^{-5}$ & 5.45 \\
\hline $6-10$ & 9.2 & 9.8 & 10.0 & 1.14 & 1.01 & 0.0349 & $7.2 \times 10^{-5}$ & 7.32 \\
\hline $10-20$ & 11.5 & 12.1 & 12.5 & 1.08 & 1.01 & 0.0252 & $7.0 \times 10^{-5}$ & 22.23 \\
\hline
\end{tabular}

\subsection{Synthetic Construction Site Runoff}

Although surface runoff flows over construction sites including sediment and other pollutants (i.e., building materials, concrete washout, paint, fuel, wastewater, oil, and solvents), the filtration experiments mainly focused on the removal of TSS since most stormwater pollutants including heavy metals and nutrients were attached to TSS during the rainfall events $[7,15]$. In the field investigations of surface runoff from construction sites located in Sejong city of Republic of Korea, TSS concentration and turbidity during the dry season were observed to be 501-580 mg/L and 303-362 NTU, respectively, whereas TSS concentration and turbidity during the rainy season were observed to be $1720-2300 \mathrm{mg} / \mathrm{L}$ and 1374-3500 NTU, respectively [16]. Therefore, in this study, the synthetic construction site runoff was prepared by mixing suspended sediments collected in construction sites and tap water for target TSS concentrations of $550 \mathrm{mg} / \mathrm{L}$ for dry season and $2000 \mathrm{mg} / \mathrm{L}$ for rainy season.

Considering that particle size $(d)$ of solids in stormwater runoff were mainly less than $250 \mu \mathrm{m}$ with $d_{50}$ for highway sediments around $100 \mu \mathrm{m}$ [17], suspended sediments were collected in construction sites and were passed through No. $80(d=180 \mu \mathrm{m})$ sieve. Then, certain amounts of suspended sediments finer than sieve diameter of $180 \mu \mathrm{m}$ were mixed with tap water in the inflow water tank $\left(\mathrm{V}=3 \mathrm{~m}^{3}\right)$ and were stirred using a submersible water pump (1/2 HP Sump Pump, Shinhanil Co., Korea) during the experiments. Thus, relatively constant target TSS concentrations were maintained for inflow during the filtration experiments.

\subsection{Lab-scale Single-layer and Pilot-scale Multi-layer Filtration Apparatus}

As shown in Figure 1, both the lab-scale single-layer and pilot-scale multi-layer filtration apparatus were manufactured using transparent acryl to observe the clogging, piezometer ports to measure the hydraulic head, and sampling ports to collect water samples at the designated height of BA filter media. In addition, detail specifications and properties of both lab-scale single-layer and pilot-scale multi-layer filtration apparatus are summarized in Table 2. As summarized in Table 2, the lab-scale single-layer filtration apparatus was a circular single column whereas the pilot-scale multi-layer filtration apparatus was rectangular multi columns.

The BA filter media with different particle sizes were packed into the filtration apparatus and compressed with a plunger to minimize side-wall flow. After packing, the filtration apparatus was flushed with $\mathrm{CO}_{2}$ gas, and a minimum of two pore volumes of deionized water was displaced through the filtration apparatus prior to the start of the filtration tests using the synthetic construction site 
runoff with high TSS concentrations. The filtration apparatus packed with BA filter media used in this study was believed to mimic the un-compacted in situ filter media with greater than the recommended minimum depth (i.e., $50 \mathrm{~cm}$ ) of gravel filter bed [4].

Various volumetric flow rates simulating surface runoff flowing over construction sites were pumped through the base plate with mesh in an upward direction to provide a relatively uniform flow using a peristaltic pump (Masterflex, Cole-Parmer Instrumental Co., IL, USA). In each filtration experiment, experiments were terminated when the premature or complete clogging of BA filter media with TSS was observed. Like Segismundo et al. [7], clogging was defined as premature versus complete clogging in this study. While premature clogging is a state where hydraulic head measured at piezometer port increased to greater than $50 \%$ of the initial hydraulic head, complete clogging is a state where the hydraulic head measured at piezometer port increased to greater than $50 \%$ of the initial hydraulic head and the outflow quantity decreased to less than $20 \%$ of the initial outflow [7].

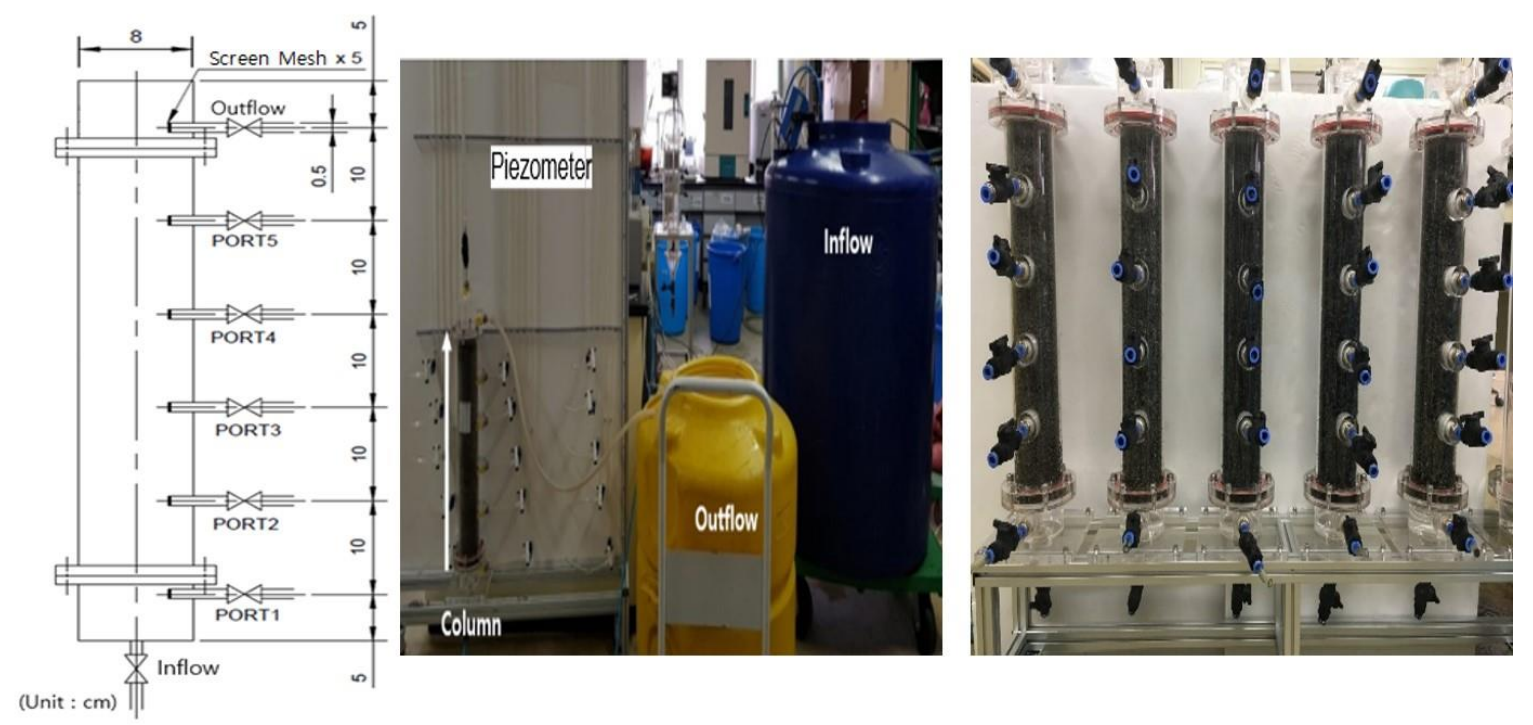

(a) Lab-scale single-layer filtration apparatus

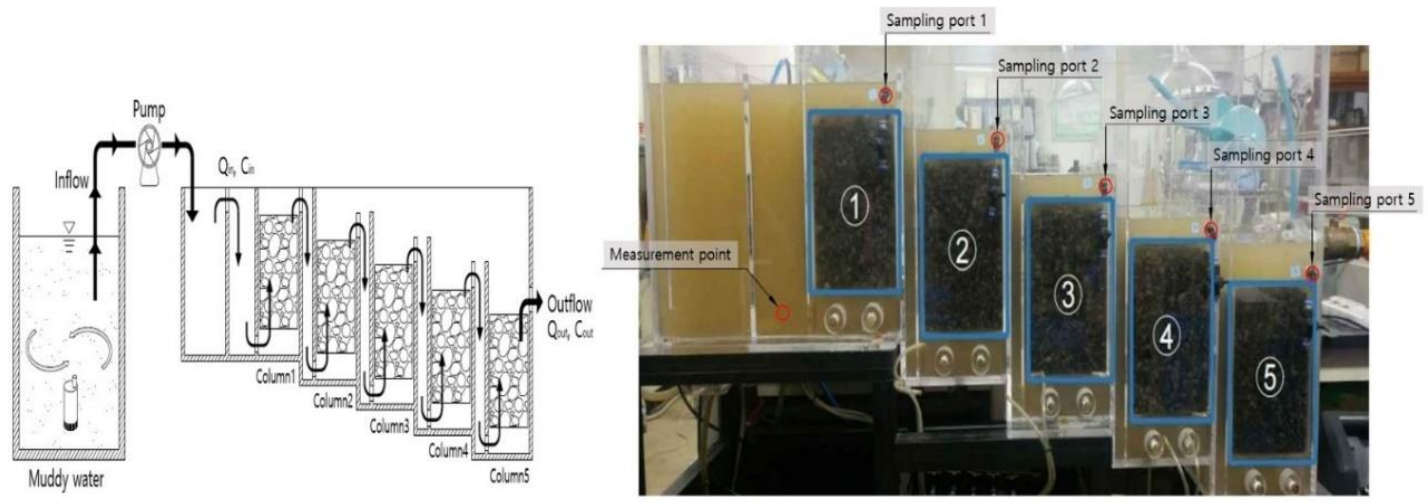

(b) Pilot-scale multi-layer filtration apparatus

Figure 1. Schematic diagram and pictorial view of both lab-scale single-layer and pilot-scale multi-layer filtration apparatus using bottom ash filter media and simulated construction site runoff. (a) Lab-scale single-layer filtration apparatus; (b) Pilot-scale multi-layer filtration apparatus. 
Table 2. Specification and properties of both lab-scale single-layer and pilot-scale multi-layer filtration apparatus using bottom ash filter media.

\begin{tabular}{|c|c|c|c|c|c|c|c|c|c|}
\hline \multirow{2}{*}{$\begin{array}{l}\text { Lab-scale } \\
\text { Single-layer }\end{array}$} & \multicolumn{3}{|c|}{ BA1 } & \multicolumn{3}{|c|}{ BA2 } & \multicolumn{3}{|c|}{ BA3 } \\
\hline & BA1a $^{1}$ & BA1b $^{2}$ & BA1c ${ }^{3}$ & BA2 $a^{1}$ & BA2 $b^{2}$ & $\mathrm{BA} 2 c^{3}$ & ВA3 $a^{1}$ & BA3b ${ }^{2}$ & BA3 $3 c^{3}$ \\
\hline Cross-sectional area, $A\left(\mathrm{~cm}^{2}\right)$ & & & & & 50.24 & & & & \\
\hline Total volume, $V_{T}\left(\mathrm{~cm}^{3}\right)$ & & & & & 2512 & & & & \\
\hline Length, $L(\mathrm{~cm})$ & & & & & 50 & & & & \\
\hline Particle size, $D(\mathrm{~mm})$ & & $3-6$ & & & $6-10$ & & & $10-20$ & \\
\hline Bottom ash weight, $W_{B A}(\mathrm{~g})$ & 1835 & 1922 & 1881 & 2215 & 2096 & 2164 & 1970 & 2007 & 2121 \\
\hline Bulk density, $\rho_{b}\left(\mathrm{~g} / \mathrm{cm}^{3}\right)$ & 0.73 & 0.76 & 0.75 & 0.88 & 0.83 & 0.86 & 0.78 & 0.80 & 0.84 \\
\hline Void ratio, $e\left(V_{V} / V_{S}\right)$ & 1.39 & 1.27 & 1.32 & 1.04 & 1.20 & 1.13 & 1.17 & 1.21 & 1.09 \\
\hline Porosity, $n\left(V_{V} / V_{T}\right)$ & 0.58 & 0.56 & 0.57 & 0.51 & 0.54 & 0.53 & 0.54 & 0.55 & 0.52 \\
\hline Pore volume, $V_{p}\left(\mathrm{~cm}^{3}\right)$ & 1457 & 1407 & 1431 & 1281 & 1373 & 1336 & 1356 & 1378 & 1314 \\
\hline
\end{tabular}

${ }^{1}$ Linear velocity $(v)=200 \mathrm{~m} / \mathrm{d} ;{ }^{2}$ Linear velocity $(v)=500 \mathrm{~m} / \mathrm{d} ;{ }^{3}$ Linear velocity $(v)=1000 \mathrm{~m} / \mathrm{d}$;

\begin{tabular}{|c|c|c|c|c|c|}
\hline $\begin{array}{c}\text { Pilot-Scale } \\
\text { Multi-layer } \\
(D=10-20 \mathrm{~mm})\end{array}$ & Column1 & Column2 & Column3 & Column4 & Column5 \\
\hline Cross-sectional area, $A\left(\mathrm{~cm}^{2}\right)$ & & & 508.4 & & \\
\hline Total volume, $V_{T}\left(\mathrm{~cm}^{3}\right)$ & & & 11,846 & & \\
\hline Cumulative length, $L(\mathrm{~cm})$ & 23.3 & 46.6 & 69.9 & 93.2 & 116.5 \\
\hline Bottom ash weight, $W_{B A}(\mathrm{~g})$ & 8295 & 8430 & 8545 & 7855 & 8405 \\
\hline Bulk density, $\rho_{b}\left(\mathrm{~g} / \mathrm{cm}^{3}\right)$ & 0.70 & 0.71 & 0.72 & 0.66 & 0.71 \\
\hline Void ratio, $e\left(V_{V} / V_{S}\right)$ & 1.44 & 1.39 & 1.36 & 1.56 & 1.40 \\
\hline Porosity, $n\left(V_{V} / V_{T}\right)$ & 0.59 & 0.58 & 0.58 & 0.61 & 0.58 \\
\hline Pore volume, $V_{p}\left(\mathrm{~cm}^{3}\right)$ & 6984 & 6887 & 6819 & 7225 & 6901 \\
\hline
\end{tabular}

\subsection{Measurements}

During the filtration experiments, the water samples at inlet, sampling ports, and outlet were collected at the designated time intervals before complete clogging occurs. At the designated height of BA filtration apparatus, the developed hydraulic heads $(h)$ were measured at each piezometer port and hydraulic conductivities $(K)$ were estimated at the same designated time intervals. Finally, the outflow rates of the filtration apparatus were also monitored at the same designated time intervals and accumulated in the outlet water tank to evaluate the complete clogging.

Using collected water samples, TSS concentrations were measured in accordance with the standard method [18], turbidity was measured using a turbidity meter (K100-TB, Istek Inc., Korea), and particle size distribution were analyzed with the use of a laser scattering particle size analyzer (MS2000, Malvern Instruments, UK). Both detailed measurements and layering of the BA filter media to investigate the changes in $K$ values and the amount of filtered TSS in each BA filter column sections are displayed in Figure 1.

\subsection{Mass Balance Analysis}

The changes in both hydraulic and TSS loading rates between inflow and outflow were carefully monitored until premature or complete clogging occurred during the filtration experiments. For hydraulic loading rate, Darcy's law is applied based on the observations that flow rate $(Q)$ through $B A$ filter media is proportional to the cross-sectional area $(A)$ perpendicular to flow and is also proportional to the hydraulic gradient $(I=d h / d L)$ in the direction of flow. Thus, following equation can be drawn.

$$
Q=-K \cdot \frac{d h}{d L} \cdot A
$$

where $Q$ is the flow rate of synthetic construction site runoff through the BA filter media $\left(\mathrm{cm}^{3} / \mathrm{min}\right)$, $K$ is the hydraulic conductivity of the BA filter media $(\mathrm{cm} / \mathrm{min}), h$ is the hydraulic head $(\mathrm{cm}), L$ is the distance of water in the direction of flow $(\mathrm{cm})$, and $A$ is the total cross-sectional area of the BA filter media perpendicular to flow $\left(\mathrm{cm}^{2}\right)$. 
The amount of TSS loadings for inflow and outflow in the filtration apparatus were calculated using the values of both TSS concentrations and flow rates from inflow and outflow to evaluate the performance of the BA filter media with different sizes. The TSS amount of inflow and outflow were calculated by using Equations (2) and (3). Additionally, filtered amounts of TSS in BA filter media through sedimentation, infiltration, and adsorption mechanisms can be calculated based on the mass balance using Equation (4).

$$
\begin{gathered}
\text { Inflow mass }\left(M_{\text {in }}(t)\right)=\sum_{t=0}^{t=T} C_{\text {in }}(t) \cdot Q_{\text {in }}(t) \\
\text { Outflow mass }\left(M_{\text {out }}(t)\right)=\sum_{t=0}^{t=T} C_{\text {out }}(t) \cdot Q_{\text {out }}(t) \\
\text { Filtered TSS Amount }(g)=\sum_{t=0}^{t=T} C_{\text {in }}(t) \cdot Q_{\text {in }}(t)-\sum_{t=0}^{t=T} C_{\text {out }}(t) \cdot Q_{\text {out }}(t)
\end{gathered}
$$

where $C_{\text {in }}(t)$ and $C_{\text {out }}(t)$ are the TSS concentrations for inflow and outflow, respectively $(\mathrm{mg} / \mathrm{L})$, at time $t$, and $Q_{\text {in }}(t)$ and $Q_{\text {out }}(t)$ are the flow rate of synthetic construction site runoff for inflow and outflow $\left(\mathrm{cm}^{3} / \mathrm{min}\right)$, respectively, at time $t$.

Based on the mass balance, TSS removal efficiencies were determined using both the weight and cross-sectional surface area of BA filter media, respectively, as displayed in Equations (5) and (6).

$$
\begin{aligned}
& \text { Removal Efficiency }{ }_{W}(\%)=\frac{M_{\text {in }}(t)-M_{\text {out }}(t)}{W_{B A}} \\
& \text { Removal Efficiency } \text { Ef }_{A}(\%)=\frac{M_{\text {in }}(t)-M_{\text {out }}(t)}{S A_{B A}}
\end{aligned}
$$

where $W_{B A}$ and $S A_{B A}$ are the weight $(\mathrm{kg})$ and cross-sectional surface area $\left(\mathrm{m}^{2}\right)$ of BA filter media applied, respectively. Due to the lack of replication of filtration experiments, the results in this study only indicate a preliminary evaluation of BA for construction site runoff filtration and infiltration systems as an alternative filter media. Various field applications are in progress in construction sites to evaluate the filtration performance of BMPs using BA filter media.

\section{Results and Discussion}

\subsection{Physicochemical and Leaching Properties of Bottom Ash (BA)}

Although the characteristics of BA largely depend on the types of furnace and coal, and processes of pretreatment and grinding [19], BA evaluated in this study is classified as three groups of uniformly-graded particles having relatively identical particles with $C_{u}$ value approximately equal to unity, as summarized in Table 1 . Compared to high specific surface area $\left(170-2000 \mathrm{~m}^{2} / \mathrm{kg}\right)$ of silt-size fly ash [20], relatively low specific surface area $\left(25.2-39.3 \mathrm{~m}^{2} / \mathrm{kg}\right)$ of gravel-size BA was observed and decreased with the increase in particle size of BA. Due to the irregular and spherical shape of gravel-size BA used in this study, relatively low surface area, negligible pore volume, and greater pore size were observed.

As is evident by SEM images and energy-dispersive X-ray spectroscopy (EDS) displayed in Figure 2, BA used in this study consisted of mesoporous and spherical particles. This observation is mainly due to both melting and expelling of ash from BA particles through high temperature and pressure processes of pulverized coal-fired combustion [21]. In a pulverized coal-fired combustion, the furnace operating temperatures are typically over $1400^{\circ} \mathrm{C}$, where most mineral matters within the coal could be oxidized, decomposed, fused, disintegrated, or agglomerated [22]. In addition, rapid cooling in the post-combustion process results in the formation of mesoporous, spherical, and amorphous (non-crystalline) BA particles. The chemical analysis based on SEM-EDS results indicates that the 
main chemical compounds including silicates $\left(\mathrm{SiO}_{2}\right)$, aluminates $\left(\mathrm{Al}_{2} \mathrm{O}_{3}\right)$, and iron oxide $\left(\mathrm{Fe}_{2} \mathrm{O}_{3}\right)$ with other compounds in trace amounts. This result is consistent with the previous studies [21] reporting that silicates $\left(\mathrm{SiO}_{2}\right)$ was found the most abundant, aluminates $\left(\mathrm{Al}_{2} \mathrm{O}_{3}\right)$ was found the second most abundant constituent, followed by iron oxide $\left(\mathrm{Fe}_{2} \mathrm{O}_{3}\right)$.
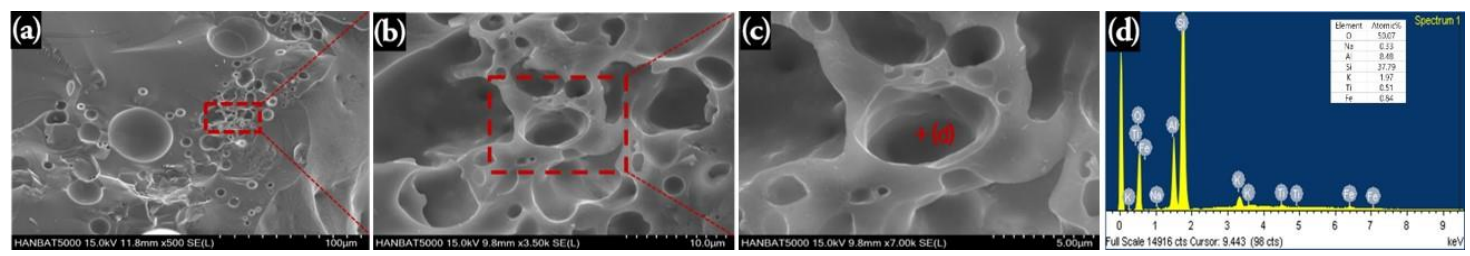

Figure 2. Scanning electron microscopic images at different resolutions (i.e., (a) 500x; (b) 3500x; and (c) $7000 \times$ ) integrated with an energy dispersive $X$-ray spectrometer analyses of bottom ash collected from coal-fired power plants.

Although BA in this study has lower potential to leach trace elements considering larger particle sizes with low specific surface area, both leaching of heavy metals and ecological toxicity were investigated using the Korean leaching test (KLT) method, sequential extraction method, and acute toxicity test using Daphnia magna. From the results, only trace amounts of Cu were leached at limit of quantitation whereas other heavy metals were not leached [13]. Through the sequential extraction, the relatively high leaching potential of $\mathrm{Cu}$ was observed due to greater fraction of exchangeable and bound to carbonates [13]. However, acute toxicity tests using Daphnia magna display no impact for mobilization and lethality for BA from either pre-filtration or post-filtration experiment, indicating that the ecological toxicity of BA was insignificant with zero values of toxic unit [13]. Consequently, no environmental impacts or ecological toxicity are expected when BA used in this study is applied in the stormwater filtration and infiltration systems as an alternative filter media.

\subsection{Effects of Particle Size of BA and Loading Rate of TSS in Single-layer Filtration}

The removal efficiencies and filtered amounts of TSS were displayed in Figure 3 using different particle sizes of BA filter media and loading rates of TSS in lab-scale single-layer filtration apparatus. For relatively low loading rate of TSS (Figure 3a,b), the removal efficiencies of TSS using BA filter media were greater than $40 \%$. In addition, filtered amounts of TSS similarly increased in the S-shaped curve (sigmoid curve) and did not reach the maximum filtered amounts of TSS for all BA filter media, irrespective of particle size of BA. These results are mainly attributed to the presence of enough retention time and sustainable pore spaces for sedimentation, infiltration, and adsorption of TSS in the BA filter media with all particle sizes without clogging due to the slow loading rate of TSS.

However, for relatively moderate loading rate of TSS (Figure 3c,d), the initial removal efficiencies of TSS for BA1 ( $D=3-6 \mathrm{~mm}$ ) were similar to those from low loading rate of TSS, however, removal efficiencies of TSS for BA1 gradually decreased after development of premature clogging. On the contrary, removal efficiencies of TSS for BA2 $(D=6-10 \mathrm{~mm})$ and BA3 $(D=10-20 \mathrm{~mm})$ were greater than $40 \%$ without significant decrease in TSS removal efficiency. Whereas the filtered amounts of TSS similarly increased in S-shaped curve without reaching the maximum filtered amounts for BA2 and BA3, those increased linearly and reached the maximum filtered amounts for BA1. These results suggest that pore spaces and flow paths through BA1 filter media were gradually blocked with accumulated TSS which induced the clogging with greater loading rates of TSS. 


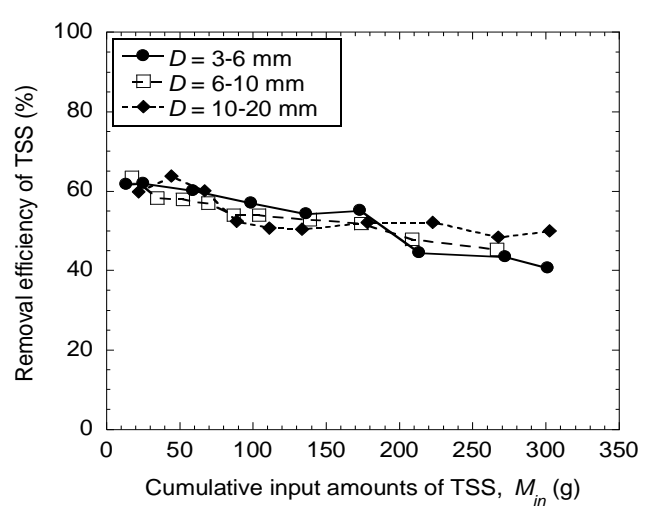

(a) Removal efficiency @ $v=200 \mathrm{~m} / \mathrm{d}$

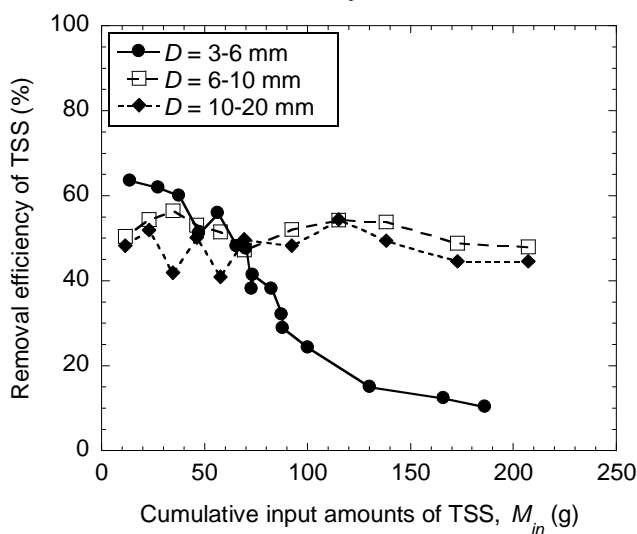

(c) Removal efficiency @ $v=500 \mathrm{~m} / \mathrm{d}$

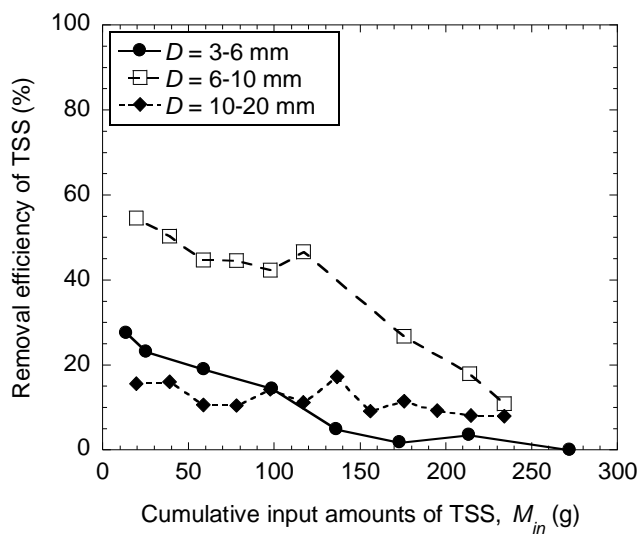

(e) Removal efficiency @ $v=1000$ m/d

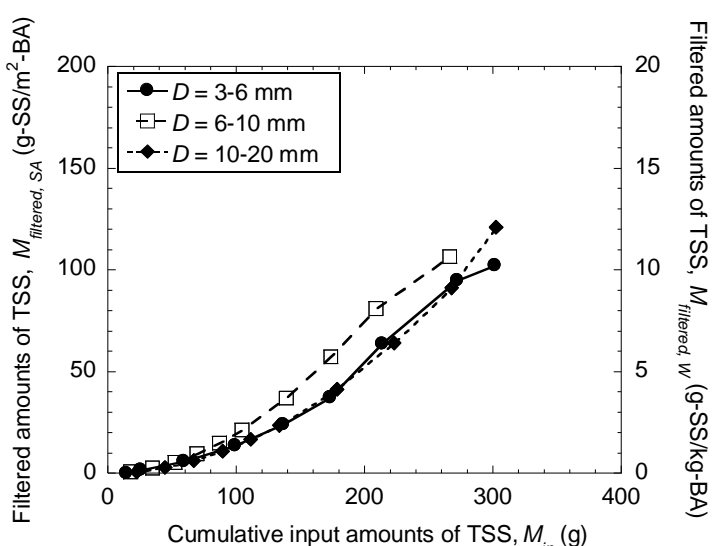

(b) Filtered amounts@ $v=200 \mathrm{~m} / \mathrm{d}$

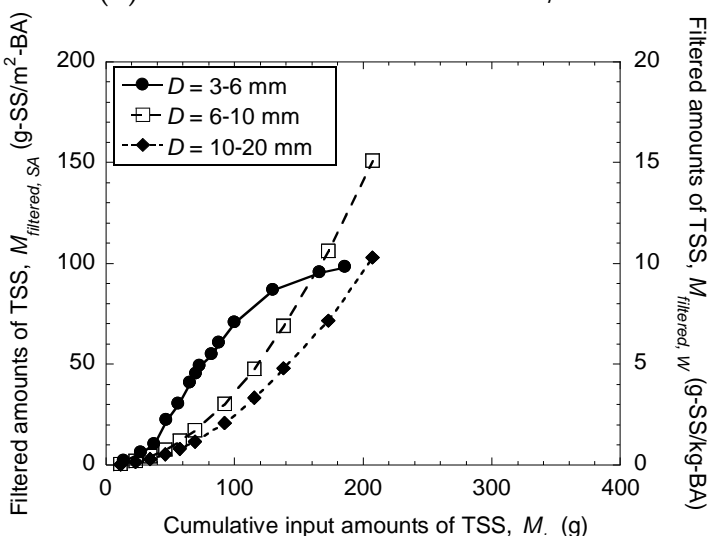

(d) Filtered amounts @ v = 500 m/d

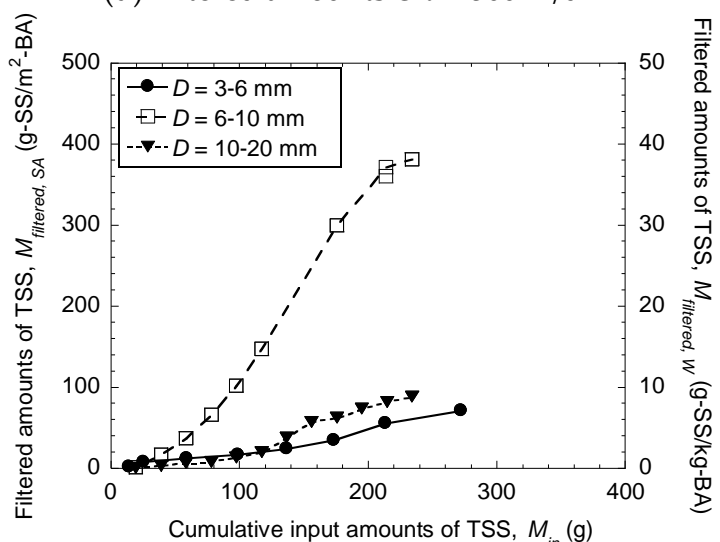

(f) Filtered amounts @ v=1000 m/d

Figure 3. Comparison of removal efficiency of total suspended solids (TSS) and filtered amount of TSS based on unit weight and surface area for bottom ash with different particle sizes in terms of the changes in linear velocity $(v)$ of synthetic construction site runoff. (a) Removal efficiency @ $v=200 \mathrm{~m} / \mathrm{d}$; (b) Filtered amounts @ v=200 m/d; (c) Removal efficiency@v=500 m/d; (d) Filtered amounts@ $v=$ 500 m/d; (e) Removal efficiency @ v=1000 m/d, and (f) Filtered amounts @ v=1000 m/d.

As expected, for relatively high loading rate of TSS (Figure 3e,f), the removal efficiencies of TSS for all BA filter media with different particle sizes decreased, however, the decreasing rate of removal efficiencies of TSS was faster for BA with smaller particle sizes. Additionally, the filtered amounts of TSS similarly increased in the S-shaped curve and approached nearly the maximum filtered amounts for all BA filter media. Thus, TSS removal efficiencies using BA filter media were a complex function of particle size of BA filter media and loading rate of TSS, and BA2 $(D=6-10 \mathrm{~mm})$ resulted in the greater 
TSS removal efficiencies and longer operational period in this study. Consistent with these results, the characteristics of both filter media (i.e., shape, size, depth, and arrangement) [4-7] and surface runoff (i.e., inflow rates, sediment concentration, sediment particle size, and distribution) [5-8] need to be considered to optimize the TSS removal efficiencies in infiltration/filtration facilities.

\subsection{Estimation of Premature and Complete Clogging in Single-layer Filtration}

As displayed in Figure 4, changes in both hydraulic conductivity $(K)$ and hydraulic head $(h)$ with different particle size of BA at linear velocity $(v)$ of $1000 \mathrm{~m} / \mathrm{d}$ suggested both premature and complete clogging. Since the deposition of TSS inside small-sized (micropores), intermediate-sized spaces (mesopores), and larger spaces (macropores) among individual BA particles can reduce both pore spaces and infiltration rate, significant decrease in $K$ and increase in $h$ were observed in all BA filter media. However, earlier development of clogging for BA1 with smaller particle size $(D)$ than that for BA2 and BA3 was observed because the entrapment and entrainment of TSS along with particle rearrangement easily decreased pore spaces of BA1 with smaller particle size. Thus, both generation and duration of clogging in the BA filter media were also a function of particle size of BA filter media and TSS loading rate. Since BA filter media with smaller particle sizes are prone to clogging, the effective area available for infiltration are reduced, and treated hydraulic and TSS loading decreased for construction site runoff. Thus, further experiments were rigorously tested and monitored in situ and in parallel through pilot-scale multi-layer filtration apparatus using BA3 filter media with particle size $(D)$ of $10-20 \mathrm{~mm}$.

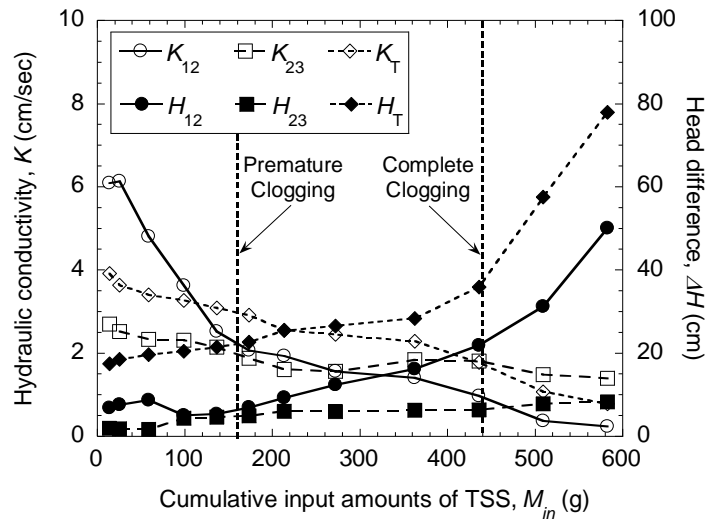

(a) $D=3-6 \mathrm{~mm}$

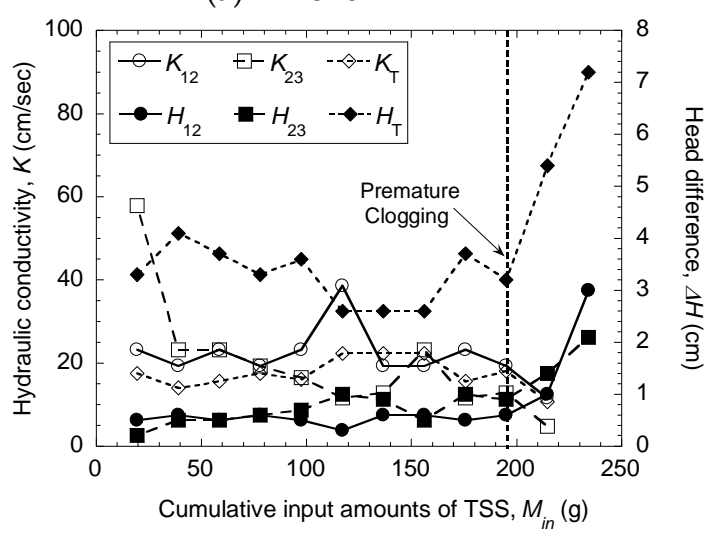

(c) $D=10-20 \mathrm{~mm}$

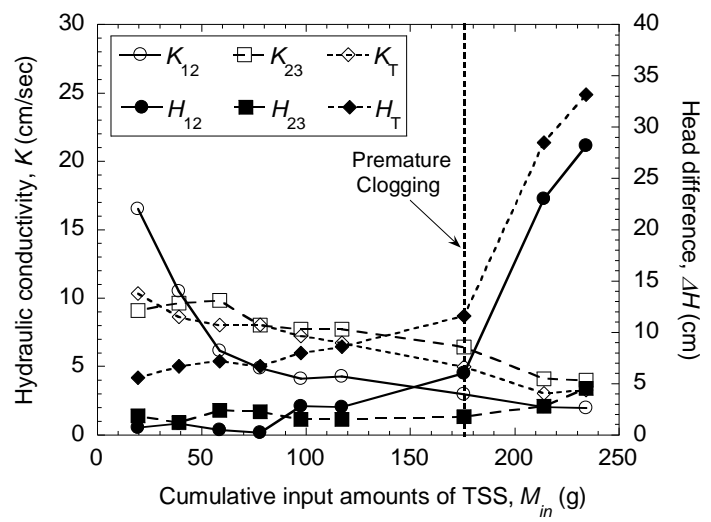

(b) $D=6-10 \mathrm{~mm}$

Figure 4. Changes in both hydraulic conductivity and head difference for bottom ash with different particle sizes at linear velocity (v) of $1000 \mathrm{~m} / \mathrm{d}$. (a) $D=3-6 \mathrm{~mm}$; (b) $D=6-10 \mathrm{~mm}$; (c) $D=10-20 \mathrm{~mm}$. 


\subsection{Removal Efficiency of TSS in Pilot-Scale Multi-layer Filtration}

Changes in removal efficiencies of TSS for each BA column of pilot-scale multi-layer filtration apparatus were displayed in Figure 5a,b. Consistent with other studies [7,23-25], cumulative TSS removal efficiencies increased with an increase in BA filter media depth. However, the distributions of the amount of TSS accumulated in each BA filter column were different, were highest at the upper layer (i.e., Column 1), and decreased with the depth of the BA filter media. In addition, more than $70 \%$ of the total amount of TSS accumulated was deposited within the upper two layers (i.e., Columns 1 and 2) corresponding to BA media depth of $46 \mathrm{~cm}$. These results indicated that most captured TSS deposit within upper layers $(\leq 46 \mathrm{~cm})$ of BA filter media, and both depth filtration and clogging filtration simultaneously contribute to entrap TSS from construction site runoff.
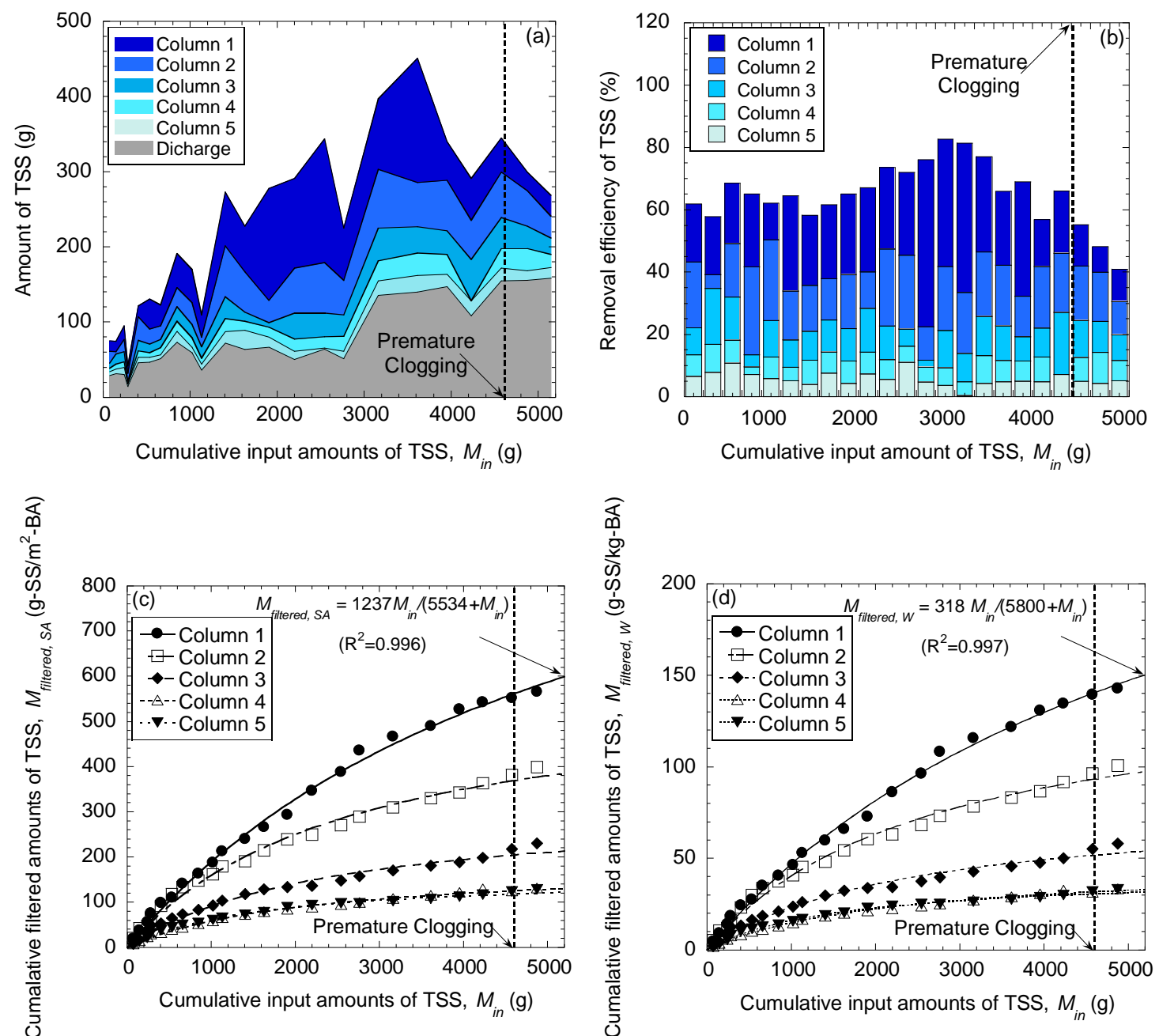

Figure 5. Changes in removal efficiencies and cumulative filtered amounts of TSS for each bottom ash (BA) column of pilot-scale multi-layer filtration apparatus. (a) Amount of TSS; (b) Removal efficiency of TSS; (c) Cumulative filtered amounts of TSS in terms of surface area of BA; (d) Cumulative filtered amounts of TSS in terms of weight of BA.

As indicated by Figure $5 c, d$, the decrease in the cumulative filtered amounts of TSS with the depth of BA filter column were clearly observed, indicating that the clogging layer formation and clogging-limited performance within upper layers of BA filter media are significant. Both settlement and stacking of larger TSS particles within upper layers of BA filter media form clogging layer, the formed clogging layer enhances the TSS removal efficiency by limiting the pore spaces to filter 
media, and slower infiltration rate is expected to increase the residence time of the construction site runoff.

Finally, the efficiency of the sedimentation process increased within upper layers of BA filter media, allowing more time for the TSS to settle over the clogging layer. Thus, incoming TSS particles do not significantly penetrate beyond $46 \mathrm{~cm}$ of BA filter media, accumulating on the upper layers of BA filter media and gradually forming a clogging layer to critical thickness until the clogging filtration mechanism dominates the overall removal efficiency of TSS. Additionally, beneath this clogging layer, BA filter media are assumed to have minimal accumulation of TSS.

Consistent with this study, $60 \%$ of TSS is removed within the first $10 \mathrm{~cm}$ of a sand filter due to the clogging [25], and 70\% of TSS from synthetic runoff was filtered through BA filter media with various TSS removal efficiencies according to different hydraulic loading rates and inflow concentrations [26]. In addition, Segismundo et al. [7] reported that the amount of TSS accumulated in BA and sand mixture columns were greater than $70 \%$ at the upper $15 \%$ of depth, and then rapidly decreased as it reached the bottom due to the formation of a clogging layer at the top surface of the filter column. Although the formation of a clogging layer increased the sedimentation process of TSS due to the longer residence, both infiltration and adsorption of TSS beneath this clogging layer were limited and the volume of TSS filtering capacity were reduced.

Similar to the results from single-layer filtration apparatus, the filtered amounts of TSS increased in the S-shaped curve (sigmoid curve) as displayed in Figure $5 \mathrm{c}, \mathrm{d}$. Considering that the clogging area development can be divided into rapid clogging section fitted by a logistic function, clogging recovery section fitted by a linear function, and stable clogging fitted by a horizontal linear line [27], the lumped empirical model based on a simplified sigmoidal function was fitted to the cumulative filtered amounts of TSS for each BA filter column. As summarized in Table 3 showing the excellent representation of cumulative filtered amounts of TSS at cumulative TSS loadings (i.e., $R^{2} \geq 0.982$ ) using a simplified sigmoidal function, the cumulative filtered amounts of TSS at cumulative TSS loadings were estimated at complete clogging. Although TSS removal through BA filter media was attributed to the mixed mechanisms of depth filtration, cake filtration, and surface straining, the cake filtration mechanism eventually dominates the overall TSS filtration efficiency [23,24]. Thus, accumulation of TSS on BA filter media can be explained by lumped sigmoidal function, suggesting that accumulation of TSS on BA filter media increases nonlinearly to threshold maximum values, and, above the threshold maximum values, no more accumulation of TSS on BA filter media is expected due to the bypass or washout of construction site runoff.

Table 3. Summary of cumulative filtered amounts of TSS for each BA filter column measured at premature clogging and estimated at complete clogging in pilot-scale multi-layer filtration apparatus.

\begin{tabular}{|c|c|c|c|c|c|c|}
\hline \multirow[b]{2}{*}{$\begin{array}{l}\text { Column } \\
\text { Title }\end{array}$} & \multicolumn{2}{|c|}{ Premature Clogging } & \multicolumn{4}{|c|}{ Complete Clogging } \\
\hline & $\begin{array}{c}M_{\text {filtered, }} \text { SA } \\
\left.\text { (g-TSS/m }{ }^{2}-\mathrm{BA}\right)\end{array}$ & $\begin{array}{c}M_{\text {filtered, }} \text { } \\
\text { (g-TSS/kg-BA) }\end{array}$ & $\mathbf{R}^{2}$ & $\begin{array}{c}M_{\text {filtered, }} \text { SA } \\
\left.\text { (g-TSS/m }{ }^{2}-\mathrm{BA}\right)\end{array}$ & $\begin{array}{c}M_{\text {filtered, }} W \\
\text { (g-TSS/kg-BA) }\end{array}$ & $\mathbf{R}^{2}$ \\
\hline Column1 & 576 & 142.9 & 0.996 & 1237 & 318 & 0.997 \\
\hline Column2 & 334 & 84.4 & 0.991 & 582 & 147 & 0.991 \\
\hline Column3 & 175 & 44.2 & 0.981 & 311 & 78.7 & 0.982 \\
\hline Column4 & 128 & 32.3 & 0.992 & 184 & 46.3 & 0.992 \\
\hline Column5 & 96.1 & 24.7 & 0.990 & 159 & 41.0 & 0.989 \\
\hline
\end{tabular}

\subsection{Estimation of Filtered Amounts of TSS with the Depth of BA Filter Media}

Since several important design and maintenance issues in BA filter media to treat construction site runoff including the formation of the clogging layer and the appropriate media depth for TSS removal need to be investigated, both experimental filtered amounts of TSS at premature clogging and estimated filtered amounts of TSS at complete clogging were analyzed in Figure 6. As analyzed in Figure 6a, cumulative filtered amounts of TSS at premature clogging fitted to a simplified sigmoidal function (i.e., $\left.R^{2} \geq 0.999\right)$ increased rapidly to $46 \mathrm{~cm}$ depth of filter media whereas those slowly increased toward 
asymptotic maximum values after $46 \mathrm{~cm}$ depth of filter media. In addition, the experimental filtered amounts of TSS at premature clogging exponentially decreased with the depth of BA filter media as analyzed in Figure 6a (i.e., $R^{2} \geq 0.985$ ).
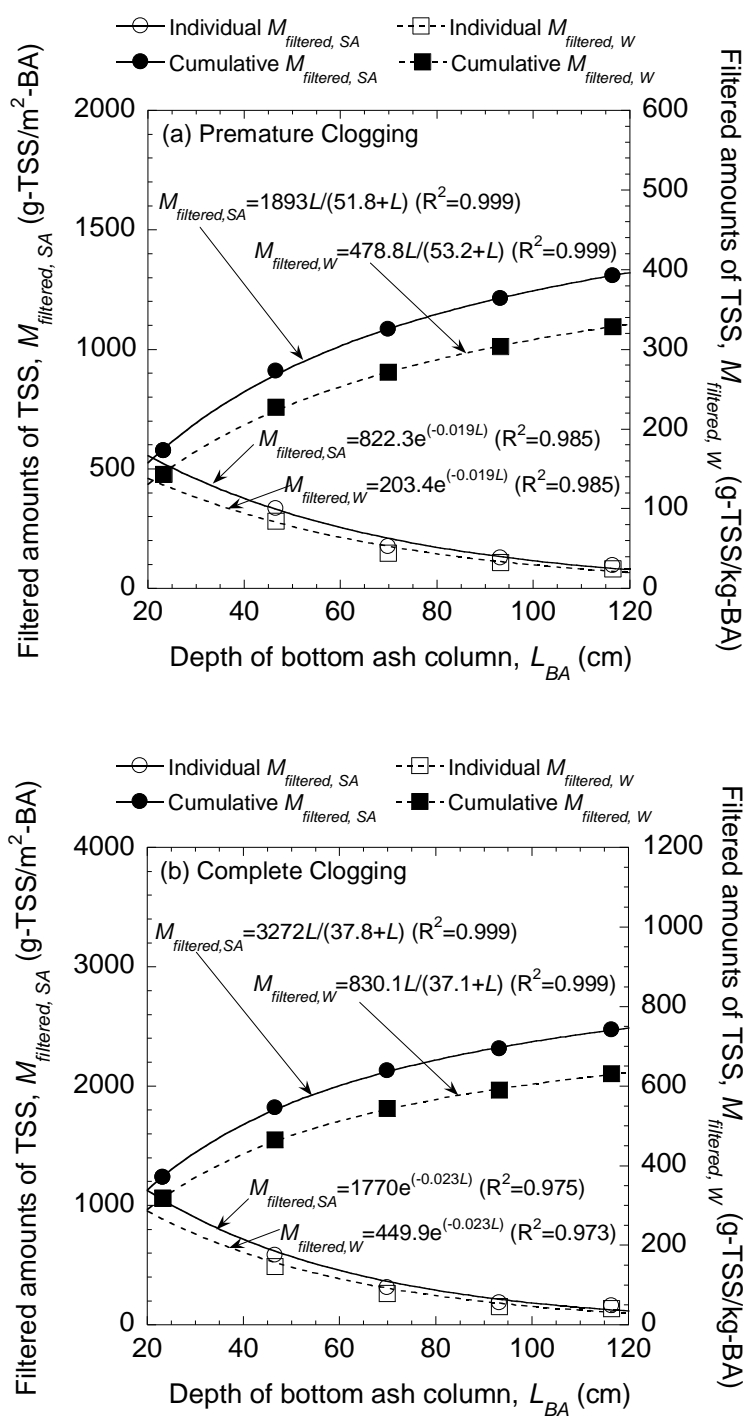

Figure 6. Changes in filtered amount of TSS with depth of the BA column in terms of surface area and weight of bottom ash. (a) Experimental filtered amounts of TSS at premature clogging, and (b) estimated filtered amounts of TSS using at complete clogging.

Consequently, most captured TSS deposit within upper layers $(\leq 46 \mathrm{~cm})$ of BA filter media, and clogging filtration is more dominant mechanism than depth filtration for TSS removal using BA media filter. Considering that early development of clogging by capturing the TSS through sedimentation, infiltration, and adsorption mechanisms is expected within upper layers, the suitable depth of BA filter media ranged from 40 to $50 \mathrm{~cm}$, and this relatively shallow BA filter bed is more beneficial for hydraulic and maintenance reasons.

The filtered amounts of TSS at complete clogging were also estimated in Figure $6 \mathrm{~b}$. Identical to the experimental filtered amounts of TSS at premature clogging, the estimated filtered amounts of TSS at complete clogging exponentially decreased with the depth of BA filter media (i.e., $R^{2} \geq 0.973$ ), and cumulative filtered amounts of TSS at complete clogging fitted to a simplified sigmoidal function (i.e., $R^{2} \geq 0.999$ ) increased rapidly to $46 \mathrm{~cm}$ depth of BA filter media whereas those slowly increased toward asymptotic maximum values after $46 \mathrm{~cm}$ depth of BA filter media. Thus, incoming TSS particles 
do not significantly penetrate beyond $46 \mathrm{~cm}$ depth of filter media. Instead, most TSS particles were captured and deposited in the upper media, creating an exponential decline of deposited particle accumulations with depth and resulting in minimal accumulation beneath the upper media. Thus, the capture of TSS from construction site runoff reduces the BA media permeability and may cause clogging and filter failure.

\subsection{Removal Efficiency of Turbidity in Pilot-Scale Multi-layer Filtration}

Changes in removal efficiencies of turbidity for each BA column of pilot-scale multi-layer filtration apparatus were displayed in Figure 7a,b. Through the whole BA columns in multi-layer filtration apparatus, relatively low removal efficiencies $(\leq 50 \%)$ of turbidity were observed. Removal efficiencies for each BA filter column were different, irrespective of the depth of the BA filter media, and removal efficiencies decreased with the increase in the input amounts of TSS. Similar to this study, $33 \%-56 \%$ turbidity removal efficiency using coarse sand media $\left(d_{e}=0.50 \mathrm{~mm}\right)$ and $40 \%-62 \%$ turbidity removal efficiency using fine sand media $\left(d_{e}=0.30 \mathrm{~mm}\right)$ were reported [28]. Although removal efficiency of turbidity could increase with the decrease in particle size of BA filter media, using finer BA filter media could decrease the operational period of filtration apparatus due to the early development of clogging. Instead, turbidity removal through the longer depth of coarser BA filter media with longer retention time is more beneficial because smaller TSS particles can be filtered out as the flow passages become smaller due to the accumulated larger TSS particles.
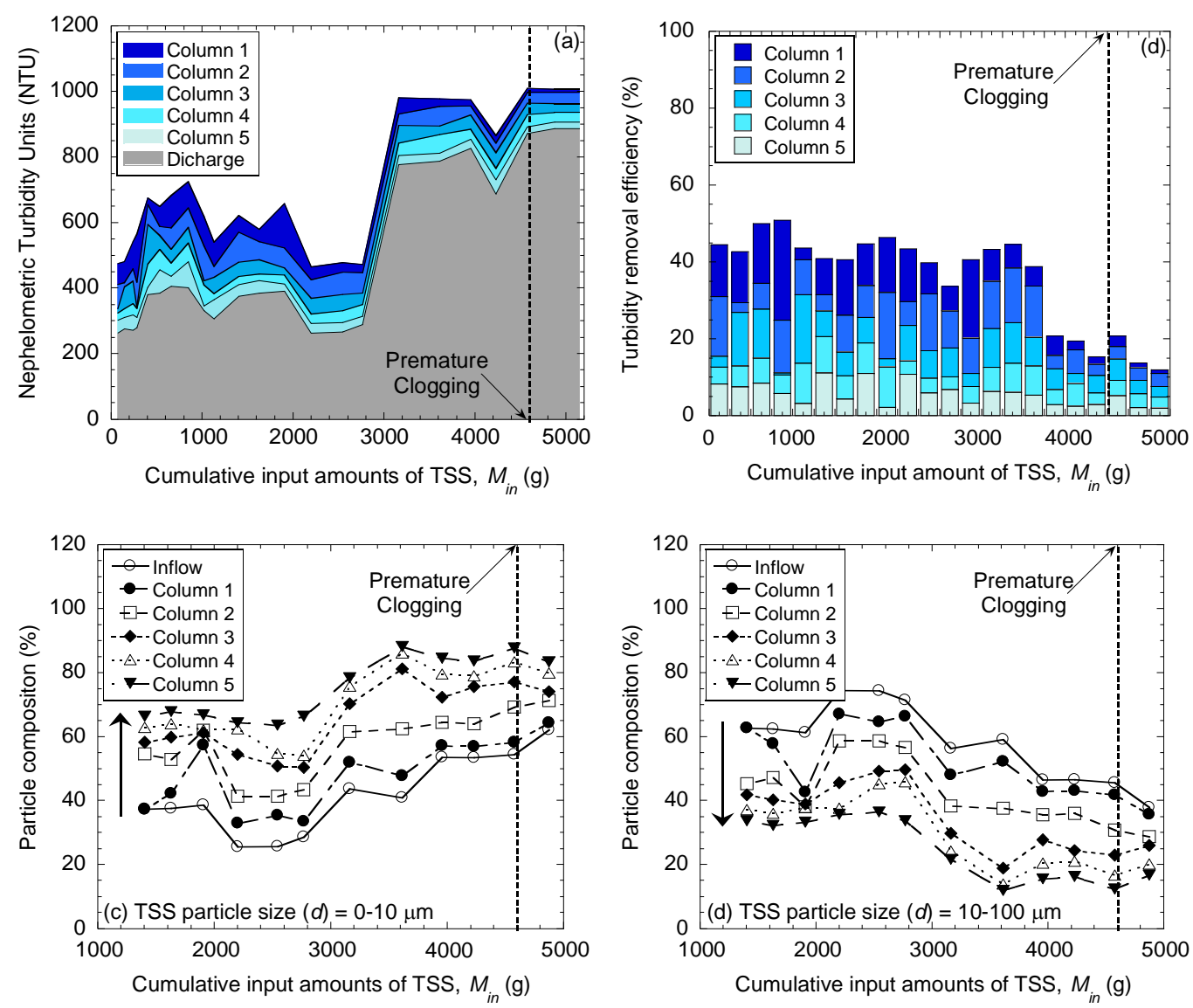

Figure 7. Changes in removal efficiencies of turbidity and fraction of particle size distribution for each BA column of the pilot-scale multi-layer filtration apparatus. (a) Nephelometric turbidity unit of synthetic construction site runoff; (b) turbidity removal efficiency; (c) TSS particle size $(d=0-10 \mu \mathrm{m})$ fraction of synthetic construction site runoff; (d) TSS particle size $(d=10-100 \mu \mathrm{m})$ fraction of synthetic construction site runoff. 
As is evident by Figure $7 c, d$, with the depth of the BA filter media, low particle size $(d=0-10 \mu \mathrm{m})$ fraction of TSS increased and high particle size $(d=10-100 \mu \mathrm{m})$ fraction of TSS decreased. These results indicate that high particle size $(d=10-100 \mu \mathrm{m})$ fraction of TSS were filtered through the BA filter media whereas low particle size $(d=0-10 \mu \mathrm{m})$ fraction of TSS passed through the BA filter media. In agreement with this study, Segismundo et al. [7] reported that a decrease of the amount of high particle size $(d=100-250 \mu \mathrm{m})$ fraction of TSS with depth is noticed which subsequently results in an increase in fraction of low particle size $(d=0-25 \mu \mathrm{m})$ fraction of TSS found at deeper depths.

Although BA filter media evaluated in this study was not so effective in removing low particle size $(d=0-10 \mu \mathrm{m})$ fraction of TSS, longer residence time with multi-media filter can remove low particle size $(d=0-10 \mu \mathrm{m})$ fraction of TSS through filter media with progressively smaller pore spaces.

Thus, larger particles can be strained out by the upper BA filter media, and smaller particles can be removed using smaller fine sand or zeolite filter media through a combination of adhesion and straining. Consequently, the dual filter media of gravel-size BA and silt-size sand/zeolite mixtures is recommended to reach the higher sediment removal efficiency on all particle sizes. However, since filtration performance of dual- or multi-media filters depends on the source water quality (types, concentration, and loading rate of TSS) and physical characteristics of the media (type, size distribution, and depth of filter media), any proposal of dual- or multi-media filters media using mixture of gravel-size BA and silt-size fine media should be rigorously tested and monitored in situ through both laboratory and field experiments.

\subsection{Comparison of TSS Removal Efficiency for Various Filter Media}

For construction site runoff BMPs, both hydraulic performances considering clogging risks and TSS removal efficiency of BA filter media are key design parameters of stormwater filtration. Thus, mass removal efficiencies of TSS in terms of input TSS loading on various filter media were compared in Figure 8. As evidenced by Figure 8, TSS removal efficiencies for various filter media appear to be highly variable. Compared to other filter media with higher TSS removal efficiencies and lower TSS loading capacities, relatively lower removal efficiencies $(\geq 50 \%)$ with higher TSS loading capacities close to $2400 \mathrm{~g} / \mathrm{m}^{2}$ were observed for BA filter media, suggesting that BA filter media evaluated in this study could provide sustainable TSS removal efficiencies with both high filter loading capacities and late development of clogging for construction site runoff.

According to the Korean regulation for nonpoint source pollution treatment for field facilities [29], TSS removal efficiency should be greater than $80 \%$ with TSS loading of $4000 \mathrm{~g} / \mathrm{m}^{2}$ on filter media. However, TSS concentrations for construction site runoff were at least 3 times higher than those for other nonpoint source pollution [16], and early development of clogging through filter media is expected for construction site runoff. Thus, conventional stormwater BMPs for urban particle control using sand filters, bioretention, infiltration trenches, grassed swales, and vegetated buffer strips may not be effective due to the higher TSS loading. Instead, the removal of TSS loadings from construction site runoff through the sedimentation occurring in detention basins is required. Thus, a combination of detention basins through sedimentation and BA filter media through sedimentation, infiltration, and adsorption can remove greater amounts of TSS from construction site runoff.

From the results of the single-layer and multi-layer filtration apparatus, BA with different sizes can be utilized as a coarse filter media with reasonable removal efficiencies ( $\geq 50 \%)$ for higher TSS loading capacities close to $2400 \mathrm{~g} / \mathrm{m}^{2}$. As practical implications, the BA filter media depth of less than $46 \mathrm{~cm}$ is recommended with dual- or multi-media filters using mixtures of gravel-size BA and silt-size fine media. Finally, a combination of detention basins and BA filter media can remove greater amounts of TSS from construction site runoff with less frequent periodic de-clogging operation and management. 


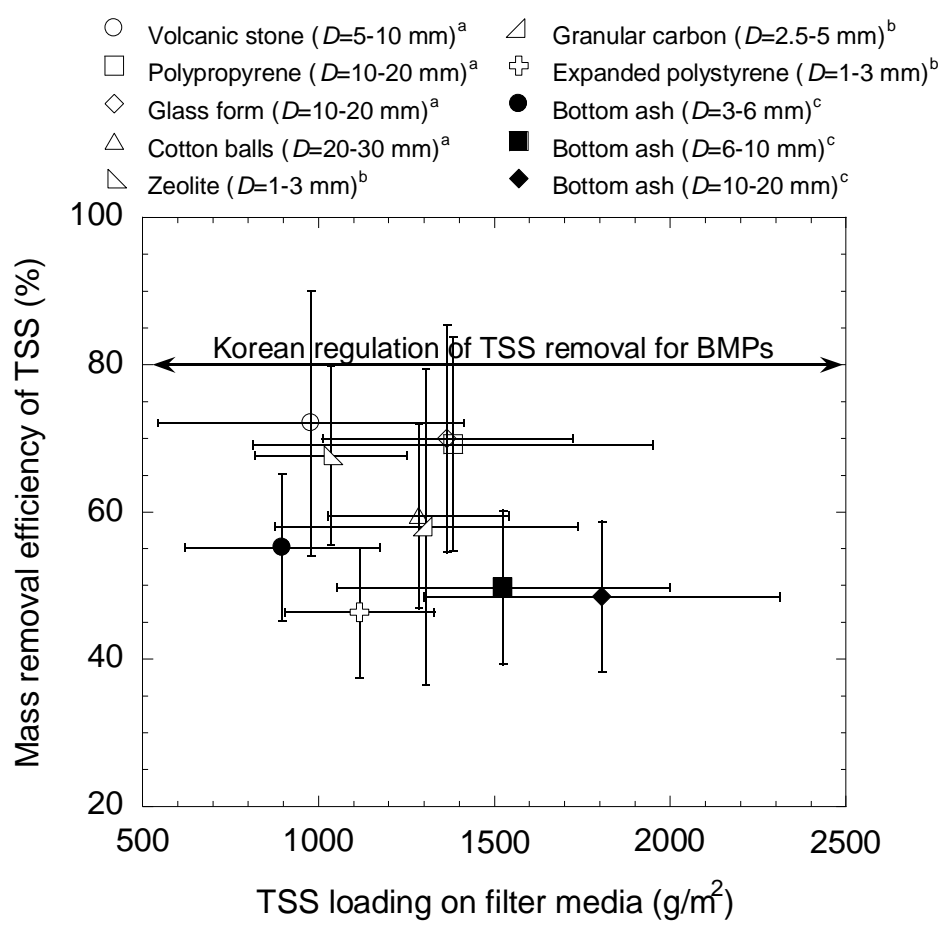

Figure 8. Comparison of mass removal efficiency of total suspended solids (TSS) for various filter media with different particle sizes before complete clogging ( ${ }^{\mathrm{a}} \mathrm{Kim}, 2016$ [30], ${ }^{\mathrm{b}} \mathrm{Kim}, 2005$ [31], and ${ }^{\mathrm{c}}$ This study).

\section{Summary and Conclusions}

The potential application of bottom ash (BA) for construction site runoff filtration and infiltration systems as an alternative filter media with high removal efficiency of TSS and longer operation period of filter system were evaluated. Both lab-scale single-layer and pilot-scale multi-layer filtration experiments were performed using BA filter media with different particle sizes and various volumetric flow rates simulating surface runoff flowing over construction sites. Due to the mesoporous, irregular, and spherical shape of gravel-size BA filter media used in this study, relatively low surface area, negligible pore volume, and greater pore size were observed. Only trace amounts of $\mathrm{Cu}$ were leached at limit of quantitation and no impact for mobilization of Daphnia magna using BA filter media from either pre-filtration or post-filtration experiment was observed, indicating that no environmental impacts or ecological toxicity are expected. For relatively high loading rate of TSS, the removal efficiencies of TSS for all BA filter media with different particle sizes decreased, however, the decreasing rate of removal efficiencies of TSS was faster for BA with smaller particle sizes. Thus, TSS removal efficiencies using BA filter media were a complex function of particle size of BA filter media and loading rate of TSS. In addition, earlier development of clogging for BA1 with smaller particle size than that for BA2 and BA3 was observed because the entrapment and entrainment of TSS along with particle rearrangement easily decreased pore spaces of BA1 with smaller particle size. Consequently, both generation and duration of clogging in the BA filter media were also a complex function of particle size of BA filter media and loading rate of TSS.

Most captured TSS deposit within upper layers $(\leq 46 \mathrm{~cm})$ of BA filter media in multi-layer filtration apparatus, and both depth filtration and clogging filtration contribute to entrap TSS from construction site runoff. Thus, incoming TSS particles did not significantly penetrate beyond 46-cm BA filter media depth, accumulating on the upper layers of BA filter media and gradually forming a clogging layer to critical thickness, and finally the clogging filtration mechanism dominates the overall removal efficiency of TSS. Additionally, accumulation of TSS on BA filter media can be explained by lumped sigmoidal function, and an exponential decline in accumulation of TSS with depth results in minimal 
accumulation beneath the upper media. High particle size $(d \geq 10 \mu \mathrm{m})$ fraction of TSS were filtered through the BA filter media whereas low particle size $(d<10 \mu \mathrm{m})$ fraction of TSS passed through the BA filter media. Accordingly, the dual filter media of gravel-size BA and silt-size sand/zeolite mixtures is recommended to reach the higher sediment removal efficiency on all particle sizes. Finally, BA filter media evaluated in this study could provide sustainable TSS removal efficiencies with both high filter loading capacities and late development of clogging for construction site runoff. As practical implications, the BA filter media depth of less than $46 \mathrm{~cm}$ is recommended with dual- or multi-media filters using mixtures of gravel-size BA and silt-size fine media. Furthermore, a combination of detention basins and BA filter media can remove greater amounts of TSS from construction site runoff with less frequent periodic de-clogging operation and management.

Author Contributions: Methodology, J.H.K. and E.K.; validation, J.C. and J.M.L.; investigation, J.H.K., E.K., and J.C.J.; resources, Y.K.; data curation, Y.K.; writing—original draft preparation, K.W.B.; writing-review and editing, J.C.J.; visualization, J.C.J.; project administration, J.C. and J.M.L.; funding acquisition, J.C., J.M.L., and Y.K. All authors have read and agreed to the published version of the manuscript.

Acknowledgments: This research was supported by the research fund of Hanbat National University in 2018.

Conflicts of Interest: The authors declare no conflict of interest.

\section{References}

1. Houser, D.L.; Pruess, H. The effects of construction on water quality: A case study of the culverting of Abram Creek. Environ. Monit. Assess. 2009, 155, 431-442. [CrossRef]

2. Chen, Y.; Viadero, R.C., Jr.; Wei, X.; Fortney, R.; Hedrick, L.B.; Welsh, S.A.; Anderson, J.T.; Lin, L.S. Effects of Highway Construction on Stream Water Quality and Macroinvertebrate Condition in a Mid-Atlantic Highlands Watershed, USA. J. Environ. Qual. 2009, 38, 1672-1682. [CrossRef]

3. U.S. Environmental Protection Agency. Stormwater Phase II Final Rule: Construction Site Runoff Control Minimum Control Measure; U.S. Environmental Protection Agency: Washington, DC, USA, 2018.

4. Hatt, B.E.; Fletcher, T.D.; Deletic, A. Treatment performance of gravel filter media: Implications for design and application of stormwater infiltration systems. Water Res. 2007, 41, 2513-2524. [CrossRef]

5. Siriwardene, N.R.; Deletic, A.; Fletcher, T.D. Clogging of stormwater gravel infiltration systems and filters: Insights from a laboratory study. Water Res. 2007, 41, 1433-1440. [CrossRef]

6. Kandra, H.S.; McCarthy, D.; Fletcher, T.D.; Deletic, A. Assessment of clogging phenomena in granular filter media used for stormwater treatment. J. Hydrol. 2014, 512, 518-527. [CrossRef]

7. Segismundo, E.Q.; Kim, L.H.; Jeong, S.M.; Lee, B.S. A Laboratory Study on the Filtration and Clogging of the Sand-Bottom Ash Mixture for Stormwater Infiltration Filter Media. Water 2017, 9, 32. [CrossRef]

8. Mercado, J.M.R.; Maniquiz-Redillas, M.C.; Kim, L.H. Laboratory study on the clogging potential of a hybrid best management practice. Desalin. Water Treat. 2015, 53, 3126-3133. [CrossRef]

9. U.S. Environmental Protection Agency. Wastewater Technology Fact Sheet: Intermittent Sand Filters; Technical Report; U.S. Environmental Protection Agency: Washington, DC, USA, 1999.

10. Clark, S.; Pitt, R. Stormwater Treatment at Critical Areas: Evaluation of Filtration Media; Technical Report; U.S. Environmental Protection Agency: Cincinnati, OH, USA, 1999.

11. Shammaa, Y.; Zhu, D.Z. Techniques for Controlling Total Suspended Solids in Stormwater Runoff. Can. Water Resour. J. 2001, 26, 359-375. [CrossRef]

12. Kang, E.B.; Joo, J.C.; Bang, G.W.; Kim, J.H.; Park, B.U.; Choi, J.S.; Kim, Y.H. A Study on Filtration Characteristics of Turbid water in Construction Sites using Bottom Ash as Filter Media I. Lab Scale Upflow Filtration Column Experiment. J. Korean Soc. Environ. Eng. 2019, 41, 89-99. [CrossRef]

13. Kim, J.H.; Joo, J.C.; Kang, E.B.; Choi, J.S.; Lee, J.M.; Kim, Y.H. Assessment of Heavy Metal Leaching and Ecological Toxicity of Reused Coal Bottom Ash for Construction Site Runoff Control. J. Korean Soc. Waste Manag. 2018, 35, 561-570. [CrossRef]

14. Cho, H.N.; Ji, S.W.; Shin, H.Y.; Jo, H.J. A Case Study of Environmental Policies and Guidelines for the Use of Coal Ash as Mine Reclamation Filler: Relevance for Needed South Korean Policy Updates. Sustainability 2019, 11, 3629. [CrossRef] 
15. Mahbub, P.; Ayoko, G.A.; Goonetilleke, A.; Egodawatta, P.; Kokot, S. Impacts of traffic and rainfall characteristics on heavy metals build-up and wash-off from urban roads. Environ. Sci. Technol. 2010, 44, 8904-8910. [CrossRef]

16. Kim, J.H.; Joo, J.C.; Bang, G.W.; Kang, E.B.; Park, B.U.; Choi, J.S.; Kim, Y.H. A Study on Filtration Characteristics of Turbid water in Construction Sites using Bottom Ash as Filter Media II. Pilot-test Filtration experiment. J. Korean Soc. Environ. Eng. 2019, 41, 140-148. [CrossRef]

17. Sansalone, J.J.; Koran, J.M.; Smithson, J.A.; Buchberger, S.G. Physical Characteristics of Urban Roadway Solids Transported during Rain Events. J. Environ. Eng. 1998, 124, 427-440. [CrossRef]

18. American Water Works Association (AWWA). Standard Methods for The Examination of Water and Wastewater, 23th ed.; American Water Works Association: Denver, CO, USA, 2017.

19. Kleinhans, U.; Wieland, C.; Frandsen, F.J.; Spliethoff, H. Ash formation and deposition in coal and biomass fired combustion systems: Progress and challenges in the field of ash particle sticking and rebound behavior. Prog. Energy Combust. 2018, 68, 65-158. [CrossRef]

20. Ahmaruzzaman, M. A review on the utilization of fly ash. Prog. Energy Combust. 2010, 36, 327-363. [CrossRef]

21. Mandal, A.K.; Sinha, O.P. Review on Current Research Status on Bottom Ash: An Indian Prospective. J. Inst. Eng. India Ser. A 2014, 95, 277-297. [CrossRef]

22. Creelman, R.A.; Ward, C.R.; Schumacher, G.; Juniper, L. Relation between Coal Mineral Matter and Deposit Mineralogy in Pulverized Fuel Furnaces. Energy Fuels 2013, 27, 5714-5724. [CrossRef]

23. Li, H.; Davis, A.P. Urban Particle Capture in Bioretention Media. I: Laboratory and Field Studies. J. Environ. Eng. 2008, 134, 409-418. [CrossRef]

24. Li, H.; Davis, A.P. Urban Particle Capture in Bioretention Media. II: Theory and Model Development. J. Environ. Eng. 2008, 134, 419-432. [CrossRef]

25. Kumar, S.; Kamra, S.K.; Yadav, R.K.; Sharma, J.P. Evaluation of sand-based stormwater filtration system for groundwater recharge wells. Curr. Sci. India 2012, 103, 395-404.

26. Gorme, J.B.; Maniquiz-Redillas, M.C.; Kim, L.H. Development of a stormwater treatment system using bottom ash as filter media. Desalin. Water Treat. 2015, 53, 3118-3125. [CrossRef]

27. Zhang, J.; She, R.; Dai, Z.; Ming, R.; Ma, G.; Cui, X.; Li, L. Experimental simulation study on pore clogging mechanism of porous pavement. Constr. Build. Mater. 2018, 187, 803-818. [CrossRef]

28. Nakhla, G.; Farooq, S. Simultaneous nitrification-denitrification in slow and filters. J. Hazard. Mater. 2003, 96, 291-303. [CrossRef]

29. Ministry of Environment, Korea (MEK). Manual for Installation, Management, and Operation of Nonpoint Pollution Reduction Facilities; Ministry of Environment: Sejong, Korea, 2014.

30. Kim, S.S. A Study on Up Flow Filtering Nonpoint Source Pollutants Treatment Facilities Using Volcanic Stone Filter Media. Master's Thesis, The University of Seoul, Seoul, Korea, 2016.

31. Kim, H.J. Media Characteristics Media Characteristics of Early-stage Storm Runoff Treatment Facility or Reduction of Nonpoint Source Pollutants on the Urban Area. Ph.D. Thesis, Dankuk University, Cheonan, Korea, 2005.

(C) 2020 by the authors. Licensee MDPI, Basel, Switzerland. This article is an open access article distributed under the terms and conditions of the Creative Commons Attribution (CC BY) license (http://creativecommons.org/licenses/by/4.0/). 